\title{
Humanistic Attitude of the Present-Day European Teacher*
}

\author{
Beatrix Bačová, Eva Leláková \\ University of Žilina, Žilina, Slovakia
}

\begin{abstract}
Education is not just simple information acquisition. It represents a set of knowledge, skills, habits, cognitive abilities, interests, attitudes and values of a person. Nowadays especially issues relating to humanization of the educational process rise to prominence. Humanism puts emphasis on the overall dignity and value of human beings and their ability of self-realization. The basic condition of humanisation in education is a new defining of teacher-student relations. A teacher is expected to be humanistic and at the same time able to meet the requirements of the present days. A humanistic model of the teacher personality prefers qualities which enable him/her to implement a humanistic approach to students and respect their personalities. Personality of the teacher is a key to successful education of a high quality; it affects the nature and quality of relationships with students and a class atmosphere. Knowledge of the climate in the classroom and its influencing must be an integral part of teacher's work. A pre-condition for the teaching profession is not only the teacher's knowledge but above all his/her ability to pass this knowledge to students and apply in a teaching process also modern methods using technologies regardless whether humanistic, social or natural subjects are taught.
\end{abstract}

Keywords: education, humanisation, humanistic teacher, student, knowledgeable society

\section{Introduction}

Humanism is a movement that emphasizes dignity and value of a human being and its ability of self-realization. It characterizes a man as a whole, inimitable and unique personality with the whole complex of its internal experience. Humanism focuses on the processes of human self-realization and self-actualization and their share in the development of society. In broad terms, it is a historically changing set of views recognizing and highlighting the value of a human being and his/her personality; his/her right to freedom, happiness, development and use of his/her own powers and abilities (Zelina, 1998). It is an effort to ensure humanity and human dignity of living conditions, a review of social institutions in terms of human welfare and an effort to ensure that the principles of justice, equality, and humanity will become standards of relationships among people in their personal and social lives. If we talk about the humanistic nature of education, we have in mind such influence in which real human relations between teachers and students, but also among students, are applied and prevail. Well-known are humanistic approaches of J. A. Comenius, J. J. Rousseau, J. H. Pestalozzi, and M. Montessori which are ranked among the most significant scientists applying basic requirements on teaching and education in the past (Gáborová, 2006).

\footnotetext{
*This paper has been written with the support of European Social Fund, project "Innovation and internationalization of education-instruments to increase the quality of the University of Žilina in the European educational area" (ITMS code 26110230079). Modern education for the knowledge society/project is funded by EU.

Beatrix Bačová, PhD., Department of Mathematics, Faculty of Humanities, University of Žilina in Žilina.

Eva Leláková, PhD., Department of English Language and Literature, Faculty of Humanities, University of Žilina in Žilina.
} 
Historically, humanistic conception of teaching can be regarded as a certain peak of educational conception. This modern way of teaching, which was extended at the end of the 20th century, was preceded by the conceptions of: (1) dogmatic teaching (the 9th-16th century); (2) demonstration teaching (the 17th century-until today); (3) reforming teaching (the end of 19th and the beginning of 20th century); (4) problem-solving teaching (the beginning of 20th century-until today); (5) developing teaching (the 2 nd half of 20th century); and (6) computer teaching (the 20th century).

Orientation on students and on strengthening their active position in an educational process is characteristic for creative and humanistic conception of education which develops a new approach to solving teacher-student relationship — a partnership principle. Thus superiority and power of teacher are eliminated and students can express themselves freely. Simultaneously, the space for creativity, spontaneity and development of individuality and self-realisation of students are created. Humanisation between a teacher and a student is therefore realised on the basis of their mutual cooperation (Bajtoš, 2005).

The extent of human knowledge is constantly spreading and this is the reason why all the knowledge cannot be automatically transferred into curriculum. An educational process includes not only an external influence of a teacher but also the inner processes of student. That's why during the process examination, it is necessary to use also knowledge of psychological sciences. This fact is also valid when teaching and testing specialized university subjects (Lacková, 2010).

\section{Humanistic Psychologyin Education}

Humanistic psychology represents the latest significant movement of psychological thinking. In fact, it is a reaction on problems of the present-day man (hisloneliness, emptiness, the role of faith, authority and meaning of life). Its aim is to create an ideal environment for an ideal development of a man as a whole. The main topics of its research are the man's choice, his creativity, and self-realization. The dignity of man is considered to be the highest value (Kubáni, 1993).

Humanistic approach to education points out concentration on the development of human psychological processes. Its aim is to teach a man how he can live the life of his own, develop his inner dispositions and elemental powers so that he, as a fully-fledged person, can find the meaning of life in society (Blaško, 2013). Humanistic theories in pedagogy are based on several sources. Holism, as one of these sources, asserts that an organism behaves as a unified whole and not as a series of mutually separated parts. Its roots go back to Aristotle that is considered to be an ancestor of scientific psychology. Humanistic theory of human development represented by humanistic psychology arose in response to the crisis of behaviourism—one of the most prevalent psychological movements examining in particular behaviour of an organism (man and animal). The year 1962 is a significant milestone in the history of the humanistic movement in pedagogy since the American society for humanistic psychology was established then. One of its founders, A. H. Maslow, an American psychologist, psychiatrist and philosopher was studying a hierarchy of human needs, their motivation, and self-realisation.

Personal dignity and human development and fulfillment are considered to be the highest values by humanistic psychologists. They support lifelong education and creativity. Humanistic approach to man not only emphasizes the feeling of things and phenomena but also strives for their understanding, for the outlet of feelings and understanding into human, cultivated and creative behaviour. 
Humanistic psychology gives us stimuli that can be used also in teaching and education. It points out predominantly:

(1) development of a student as a unique personality;

(2) acceptance of a student in its entirety;

(3) support of the inner tendency of a student towards his/her self-realization;

(4) reliance on the student's own experience;

(5) overcoming self-boundaries through self-inducement and experiencing higher values (beauty, the good, love, harmony).

In humanistic psychology, a teacher-facilitator, is a person who accompanies and encourages a student in his/her efforts on the way of education and development of personal growth. Facilitating teacher trusts each individual student of any age, he/she teaches his/her students to love studying and study more. Such a teacher prefers student's experience and interests to curriculum, closely cooperates with parents, and is prepared to solve various pedagogical situations.

An American humanistic psychologist and a big Maslow's supporter, Carl Rogers, developed a theory of nondirective psychotherapy whose principles were later applied on pedagogy and called PCE (person centred education). He emphasizes that a student and not a teacher has to be at the centre of an educational process and defines teaching by the whole personality as a unified teaching on cognitive, emotional, and organismic levels. Rogers believes that a human being has a basic tendency and effort to "self-actualise", maintain and strengthen a surviving organism and adds that future required behaviour of a man is mostly influenced by the degree of self-understanding, view of oneself, self-esteem, and acceptance of responsibility for oneself (Rogers, 1998). For him, the quality and influence of a family life, economic and cultural background and its impact on the intellect development, social experience, therapy, hereditary factors and education are very important, too. Rogers works with four principles of humanistic pedagogy:

(1) authenticity, congruency-They are evident particularly in openness and sincerity, trust and transparency of what is happening in the classroom or in education; it is necessary to realise that only a sincere and open teacher-student relationship presupposes an open student-teacher relationship-This is the basis of each educational activity;

(2) acceptance-A teacher believes that each student can be better and wiser; it is necessary to believe each student and encourage him/her that he/she is able to achieve better performance;

(3) empathy - means understanding of emotions and feelings of students and their meanings at a certain moment; the aim of a teacher is to help a student to concentrate not only on his/her thoughts but also on his/her feelings; this is a movement of values from a cognitive sphere to an emotional one;

(4) self-assessment-learning of self-assessment and evaluation of other classmates and the world around; it creates conditions for self-confidence and elevates a personality to an authentic being.

\section{Humanism in Teaching and Education}

A basic requirement of humanisation of education and teaching process is a new understanding and defining of a teacher-student relationship. A student cannot be only an object of the teacher's action (from an educational point of view); he/she has to be understood and appreciated as an important subject (Cabanová, 2011). A general aim of creative and humanistic education is to develop authenticity, variety and harmony, freedom and responsibility, and creativity of the personality of an individual. These personal traits are the 
highest aim categories of personality development. Only a fully developed personality has complexly developed psychical functions (cognitivation, axiologisation and self-regulation, socialisation and communication, motivation and activation, emotionalisation, creativisation) applicable in long-life education and self-realisation in personal, social, and working life of a human being.

Table 1

General Aims of Education (Blaško, 2013)

General aims of education

(shape fully-fledged personality) creativity, variety and harmony, freedom and responsibility, authenticity

\begin{tabular}{|l|l}
\hline Key competencies & Specific teaching aims: cognitive, psychomotor, socio-affective
\end{tabular}

communication, mathematical and scientific, 4. create attitudes and value orientations

information, learning, problem-solving, $\quad 3$. develop abilities and interests

$\begin{array}{lll}\text { personal and social, working and business, } & \text { 2. obtain and develop skills and habits }\end{array}$

civic and cultural

1. obtain: knowledge

Lászlo states that humanistic education must focus attention to:

(1) bringing education to human nature - create such conditions for education and training which correspond to natural needs and patterns of the student's development and are based on his/her capabilities and interests;

(2) development of student's personality in all his/her abilities and dispositions - create and apply such educational tools which will activate a personal growth of a student as much as possible (Lászlo, 2001).

Education is a systematic development of man. It is a mutual relationship, a dialogue between two or more people, between an educator and the learner. Because of the reasons stated, education should be based on the principles of humanization and rationalization. The principle of humanization requires a harmonic development of each personality, society, and natural environment of man. It sets a certain goal for the education. In contrast, the principle of rationalization requires a thoughtful, scientifically based effort in order to acquire corresponding educational results and effectivity. Rationalization is meaningful only if it leads to a wanted development of a man and the world, and presents a means of their humanization. If we wanted to achieve high educational efficiency, we should remember that education has to be systematic and focused on the free development of a human being. To achieve that, it is necessary to formulate educational goals in a specific way. And the achieved goals need to correspond with expended efforts (Němec, 2008).

Multiple versions of humanism and several interpretations of the term "humanistic teaching" have been developed in education. However, all of them are characterized by the same essence that the application of the above mentioned principles in practice will teach students that:

(1) Their curiosity is welcome and rewarded;

(2) They can learn new things on their own, but also with their teacher's help;

(3) They have a possibility to express their creativity;

(4) They will express their feelings, thoughts and emotions more;

(5) Learning is fun and they will look forward to school;

(6) At school, they will find a space for their different interests;

(7) In order to learn some things, effort, concentration, and self-discipline are required;

(8) Learning is useful;

(9) It is appropriate to cooperate with others in order to achieve a goal.

Successful and humanistically oriented educational process has to meet the requirements of: 
(1) new understanding and defining of the relationship between a teacher and students (It is needed to exclude teacher's superiority and display of his/her power over a student);

(2) creating an optimal climate in a class (It should be a permanent part of teacher's work);

(3) creating conditions for an active work of students (It is necessary to leave students sufficient space for their creativity);

(4) getting rid of students' fear of possible mistakes and errors (creating a peaceful atmosphere in a class by a teacher);

(5) applying creative methods of learning (to teach students how to use acquired knowledge when circumstances are new or changed);

(6) limitation of the unique position of a textbook in an educational process (A teacher should use all available sources of the education-It allows students to express their opinions, attitudes, experience, and feelings);

(7) focusing the educational process on the experience sphere of a student (A teacher is supposed to talk with students about their feelings and work, how much they are interested in the studied topic, what causes their problems while they are learning, how it is possible to use a discussed subject matter in other subjects and the life itself);

(8) developing of assessing and critical thinking (A student should learn how to recognize and evaluate himself/herself and create his/her own value orientation) (Petlák, 2000).

Creation and application of the above stated requirements depend first of all on teacher. If they are supposed to be successfully applied in practice, they have to become a permanent part of teacher's work and attitude towards students.

\section{Humanistic (European) Teacher}

The profession of a teacher is often understood as a mission. Contemporary society expects a teacher to be humanistic and meet all requirements of the modern times:

(1) a high professional level;

(2) professional competencies;

(3) high human qualities and moral properties, such as honesty and justice which are not common for other members of population;

(4) requirements concerning perfect mastering of an educational and teaching strategy, and pedagogical communication means, application of information-communication technologies in an educational process and creation of a favourable climate for education.

A teacher fulfills multiple functions in an educational process. As we already stated, a teacher is the one who provides education; he/she is a tutor, facilitator, advisor, planner, diagnostician, researcher, manager, and consultant. His/her task in an educational process is to develop knowledge, abilities, and skills of students, and thus also influence their values and attitudes. At the same time, a teacher is expected to be a good listener and positive thinker and have a sense of humor. He should be patient, friendly but at the same time very demanding. At last but not the least, he is supposed to love the subject he teaches, master it, give students advice on what and how to study and encourage them in their work.

A teacher should be a role model for a student; he ought to be the one who, while teaching, demonstrates the most modern and progressive procedures. His/her teaching has to fit the needs of society. At the same time, 
a teacher is supposed to take part in the pedagogical research focused on education, teaching, or on future education of teachers. He/she should systematically examine his/her own pedagogical practice, permanently keep on his/her own improving and regularly and effectively cooperate with the teachers from other schools-They have common goals: improvement of efficiency of education and promotion and defense of a high quality of education and teaching (Black \& Howard-Jones, 2000).

The quality of teachers' work directly affects the quality of an educational level of society. A teacher's personality has a big educational importance, since it influences educational results. Without enthusiasm and feeling of satisfaction from work, it is not possible to move forward and to achieve good results with students.

A good teacher:

(1) always keeps in mind that the informative value of a school is set by students and not by educational programmes;

(2) always sets clear rules at the beginning of the process and holds on to them;

(3) is able to react correctly on improper behavior of students with an aim to prevent it from happening again;

(4) has high demands not only on students, but predominantly on himself/herself;

(5) constantly works on himself/herself and tries to improve himself/herself as much as possible;

(6) creates a positive atmosphere in a class;

(7) treats every student with the same respect;

(8) while teaching, sticks to a strictly set plan but in case of need, he appropriately adjusts it to specific circumstances;

(9) is interested in students' opinions.

Teacher-student relationship plays a key role in teacher's work. A teacher creates a relationship with each student separately and then with the class as a whole. These relationships are mutually interconnected and complement each other. They have certain limits which help to maintain a balance between a teacher and a student and keep their autonomy and inner freedom. Therefore, it is not possible to promote one of these relationships over the other. A wrong and negative relationship with individual students would leave a mark on the relationship with a class as a whole (Cabanová, 2014). On the other side, a positive relationship with a whole class of students will allow a teacher to create a certain social climate and a favourable precondition for pedagogical work. A positive relationship makes teacher's work easier, more enjoyable and successful.

Creating an affable, kind, and open relationship with students is one of basic preconditions for the teacher's educational success. At the same time, it is a part and a precondition for his/her pedagogical tact. Many mutually interrelated factors influence the quality of this relationship-The teacher's personality is the most important of them. This, on its own, still does not predetermine the results of the teacher's pedagogical activity. Together with teacher's personality, there is another factor that co-decides about the teacher-student relationship-It is a student's personality. A student is the one who intentionally or even without any purpose decides how much the teacher's personality influences him. Other factors influencing a teacher-student relationship are individuality of a student and his/her age peculiarities. The quality of the teacher-student relationship is affected by the student's relationship to studying and subject itself as well as by his/her relationship to school as an institution.

Important factors, which have an impact on the creation of proper relationship between a teacher and a student, are: 
(1) emotional way of communication — a teacher with a natural authority opens his/her feelings before a student; it makes him/her look more fully-fledged; at the same time, he/she maintains his authority by his/her expertise and correctness in dealing with a student;

(2) empathy - it begins with a deep care for a student. A teacher can guess from the facial expression, gesticulation, way of speech, the timbre of voice and from other non-verbal displays what is happening inside the student, and based on that, adjust his/her communication;

(3) acceptation - respecting a student and his/her personality;

(4) enthusiasm - teacher's work enthusiasm is transferring to a student by stimulation and motivation;

(5) humour - it lowers the tension and relieves student's stress; improves teacher-student and student-student relationships; this leads to strengthening of the class coherence;

(6) differentiation - it is used by a teacher in different phases of an educational process; depends on the level of individual students; a teacher emphasizes that part of the process which is considered to be the most important;

(7) individualization of education - is focused on an individual activity of a student; a teacher acts as an advisor and mentor - in case of student's need, he/she explains the given problem.

A humanistic approach of a teacher enables students to recognize their own values. They express their own real feelings. A teacher accepts a student for what he/she really is and teaches him/her to love and accept himself/herself and thus obtain self-esteem and better develop own genetic predispositions. Then the process of independence gaining (from dependence to independence) is making faster. This approach enables a student to learn how to be responsible for himself/herself (Gáborová, 2006).

In an educational process, a basic principle of socialization, self-creation and shaping a student's personality is presented by creativity. Creative activity makes a human being more perfect and therefore it can be ranked among human social needs. According to Zelina, creative-humanistic conception is based on cognitive and non-cognitive processes (Zelina, 1996) and four fundamental assumptions:

(1) education is more important than teaching-The need to reduce useless and ineffective teaching is pointed out;

(2) development of the highest cognitive processes - is based on the criticism of a contemporary school from the viewpoint of students' creativity and performance;

(3) structuring of non-cognitive processes - an affective taxonomy built on the processes of cognitivisation, emotionalisation, motivation, socialisation and communication, axiologisation and creativisation;

(4) a fact as an education basis - It is presented by an interaction unit: educator-child and teacher-student.

Moral-psychological conditions and work organisation at school can also help teacher's creativity development. Satisfaction with working environment, well-being and work enjoyment are extremely important. As creativity is connected with a creative activity, it requires, e.g., material-technical support in the school environment as well as information access. If the teacher is supposed to teach students being creative, he/she has to be a creative personality. It means that he should be open and empathetic towards others, tolerant to different opinions and at the same time demanding and tireless when observing problems and implementing ideas. Each creative personality is expected to be curious, independent, strongly motivated but also brave and having courageous thinking. Creative personality should be free from egoism, conflicts, and stress because creativity requires freedom also in the inner-mental world of man. And moreover, a teacher is expected to be able to identify himself/herself with the object of interest, to master an art of dialogue and group discussion 
(Maňák, 1996). Teachers who support creativity help their students to be independent, active, and responsible. They teach them to communicate openly, support their ideas, and accept their criticism. They build informal relationships and the atmosphere of trust; expect questions and welcome a creative process of problems solution. They demand from their students to assess their own learning advance. We agree with the arguments that a teacher-humanist:

(1) tolerates not only feelings, needs, interests and individual differences of students but also their problems, mistakes, and errors;

(2) supports student's independent thinking and acting, unconventional solving of problems, positive attitudes to learning, positive informal mutual relations, cooperation among students and reasonable competitiveness;

(3) requires an active and conscious discipline and responsibility and student's own opinion and self-assessment;

(4) expects and creates conditions for each student's success, open communication and inspiring ideas and criticism;

(5) rejects blind obedience and forced activity, atmosphere of fear and tension, making fun and pigeonholing of students and satisfaction with mediocrity (Kosová, 1996).

Currently, requirements for teachers are constantly increasing. In 2002, European commission proposed the following teacher's competencies:

(1) competencies related to the learning process;

(2) competencies related to the learning outcomes;

(3) constructive competency;

(4) organisational competency;

(5) interpersonal competency;

(6) gnozeological competency.

Their aim is to improve a pedagogical activity of a teacher. Nowadays, there are several models of key competencies for the programmes of basic, secondary general, and secondary vocational education. Blaško points out that education in each field should require from an individual to be able to create his/her key competencies corresponding with his/her abilities and learning predis positions; these competencies are mutually interrelated and complement one another (Blaško, 2013). These are communication, mathematical-scientific, information, and learning competencies, competencies for problems-solving, personal, social, working, business, civic and cultural competencies.

\section{Conclusion}

The aim of our school system is to change a traditional encyclopaedic, memorizing, and directive educational process into creative and human education focused on the student's activity and responsibility. A transfer from traditional education to a creative-humanistic conception is necessary. Teachers are fully aware that humanisation of an educational process is essential. But in spite of this fact, many of them still are not able to get rid of the classical directive approach to teaching. This is a difficult task not only for teachers but also for students themselves. Teachers as standard bearers of education have always been given high demands. Generally, they often manifest their indecision, low self-confidence, lack of expertise and creativity and also unevenly differentiated relationships with their students. Their strict attitude to some students alternates a 
benevolent attitude to others. Teacher's adjustment may also affect the relationship between him/her and his/her students. A correct teacher-student relationship presupposes an ability to motivate and gain a student for voluntary compliance of his/her school duties. A humanistic model of the teacher's personality prefers those qualities of a teacher which enable him/her to have a humanistic, personal relationship with a student and respect for the student's personality. On the other hand, teacher's tolerance, patience as well as a correct amount of demands cannot be forgotten.

Teachers are responsible for the development of the students entrusted to them, for their training to fulfil basic social tasks, for shaping and forming individual sides of their personalities. This responsibility places high demands on the professional and charactertraits of teachers. In practice, we often see big differences in moral, professional, pedagogical and psychological qualities of teachers. For this reason, it is necessary to change future teachers' training and focus on the development of a free personality of an educator with empathy and inner motivation, on the development of a personality able to realize modern education and change methods of education management from directive, nondemocratic, and total methods to nondirective, democratic and alternative ones.

The teacher who comes to practice has to be able to strengthen critical thinking and communication abilities of his/her students, a cooperative way of learning, independent acquisition of knowledge, active listening, problems-solving and conclusions drawing. He/she must put emphasis on personal experience and active involvement of students into teaching/learning process, teaching manners and evaluation of teaching activities in the role of students, acceptance of variability of certain styles and the use of the method of "shock"- uncovering, discovering and overcoming certain barriers in beliefs and attitudes (Pike \& Selby, 1994).

As there is no perfect person, there is no perfect teacher. However, each teacher can be successful. If he/she has creative skills that are preconditions for the development of creativity of students, then his/her creative students can achieve a desired success. It is not sufficient to have just a bookcase full of specialised literature, to know and master a theory, different methods and computer programmes. A teacher has to show a positive relationship with his/her students and passion for the teaching profession.

The idea of an educational process and the possibilities of its positive influencing are changing. Nowadays, it is clear to all of us that a future generation will need predominantly creativity and ability of lifelong education. Dynamics of changes in an educational process stresses also the need of the personality development of the teacher's profile. It means an open attitude of the teacher to all the actions around him/her, to each matter relating to his/her job. And it is humanisation that opens the space for his/her improvement.

\section{References}

Bajtoš, J. (2005). Trendy zmien osobnosti učitela v duchu tvorivo humanistickej koncepcie výchovy a vzdelávania. In Acta Humanica, Katedra pedagogiky, psychológie a sociálnych vied FPV ŽU (pp. 41-46).

Black, R. S., \& Howard-Jones, A. (2000). Reflection on best and worst teachers: An Experiental perspective of teaching. Journal of Research and Development, 13.

Blaško, M. (2013). Kvalita v systéme modernej výučby (p. 402). Košice: Technická univerzita.

Cabanová, V. (2011). Necessity of change—Reasons and impact of the implementation of Project Millennium (Slovak school system reform). In: Ku integralnościedukacjiwczesnoszkolnej. Opole: Wydawnictwo "Nowik".

Cabanová, V. (2014). Social attitudes and values of young people in the context of multicultural education. In: Communications: Scientific letters of the University of Žilina (Vol. 16, No. 3, pp. 4-8).

Gáborová, L. (2006). Uplatňovanie humanistickej psychológie vo výchove a vzdelávaní. In Psychologická revue (pp. 42-69). Prešov: Prešovská univerzita v Prešove. 
Kosová, B. (1996). Humanizačné premeny výchovy a vzdelávaniana 1. stupni ZŠ 2. skr. vyd (p. 86). Banská Bystrica: Metodické centrum.

Kubáni, V. (1993). Psychológia osobnosti (p. 71). Prešov: PdF UPJŠ.

Lászlo, K. (2001). Základy didaktiky. In: L. Višňovský, \& V. Kačání (Eds.), Základy školskej pedagogiky (p. 227). Bratislava: Iris.

Lacková, M. (2010). Acquisition of Phrasal Verbs by Slovak university students. In Zeszytynaukowe Państwowej Wyższej Szkoły Zawodowejwe Włocławku (pp. 265-279).

Maňák, J. (1996). Pedagogické otázky tvořivosti. In: Tvořivost v práci učitele a žáka: Sborník z celostátníhosemináře $k$ problematicetvorivosti v práci učitele a žáka (pp. 17-22). Brno: Paido.

Němec, P. (2008). Kyberkultura (nové informační technologie a vzdělanost; Virtuální realita a kultura). Brno: Pedagogická Fakulta Masarykovej Univerzity.

Petlák, E. (2000). Pedagogicko-didaktická práca učitel' (p. 120). Bratislava: Iris.

Pike, G., \& Selby, D. (1994). Globální výchova (p. 322). Praha: Grada.

Rogers, C. R. (1998). Způsob bytí (p. 221). Praha: Portál.

Zelina, M. (1996). Stratégie a metódy rozvoja osobnosti diet'at'a (p. 235). Bratislava: Iris.

Zelina, M. (1998). Humanizácia výchovy I (pp. 127-137). Bratislava: Pedagogická fakulta UK Bratislava. 